\title{
METODE PENYERENTAKAN BIRAHI PADA KAMBING
}

\author{
Lalu Ahmad Zaenuri ${ }^{1 *}$, Rodiah $^{1)}$, Lukman HY ${ }^{1)}$, Adji Santoso Dradjat ${ }^{1)}$, Eny Yuliani ${ }^{1)}$ \\ ${ }^{1)}$ Fakultas Peternakan, Universitas Mataram, Jl. Majapahit No. 62 Matara, 83125 \\ ${ }^{*}$ Korespondensi: ahmadzaenuri@unram.ac.id
}

\begin{abstract}
ABSTRAK
Kegiatan pengabdian kepada masyarakat sudah dilaksanakan di desa Aik Mual kecamatan Praya kabupaten Lombok Tengah yang mellibatkan tiga kelompok peternak kambing yaitu "Harapan Makmur, kelompok Geger Girang dan kelompok Sejahtera Abadi". Setiap kelompok diwakili oleh 15 orang. Populasi kambing PE diketiga kelompok tersebut kurang lebih 950 ekor yang terdiri dari berbagai tingkatan umur. Kegiatan PPM dilaksanakan dengan metode Innovative Approach yang menekankan pada pendekatan partisipatif. Evaluasi Keberhasilan pelaksanaan PPM dilakukan terhadap dua aspek yaitu respon peserta terhadap topik PPM yang diberikan dievaluasi berdasarkan antusiasme peserta selama penyuluhan yang tercermin dari keaktifan bertanya, diskusi dan tanya jawab. Kedua, evaluasi terhadap kesesuaian materi penyuluhan yang diberikan dengan kebutuhan peserta dievaluasi dengan mengajukan daftar pertanyaan dipandu oleh tim pelaksana. Hasil pelaksanaan, berdasarkan jumlah perserta yang bertanya yaitu 15 orang atau setiap kelompok diwakili oleh 5 orang anggota dapat katakan bahwa meteri PPM mendapat respon yang positipp dari peserta. Topik PPM sangat sesuai dengan keinginan dan kebutuhan peserta, dinyatakan oleh lebih dari $90 \%$ peserta. Disarankan, kegiatan PPM yang sudah dilaksanakan agar ditindak lanjuti dengan program pelayanan yaitu pelayanan sinkronisasi birahi dan sekaligus inseminasi kambing menggunakan pejantan unggul, kususnya semen beku kambing PE.
\end{abstract}

Kata kunci: estrus, inseminasi, grading up, susu segar, PE

\section{PENDAHULUAN}

Peternakan kambing Peranakan Etawah (PE) harus digalakkan terus menerus karena beberapa alasan. Pertama, kambing PE termasuk kambing tipe perah dengan potensi produksi susu yang cukup tinggi. Kedua air susu segar dan susu bubuk yang beredar luas dimasyarakat berasal dari air susu sapi. Ketiga, air susu kambing mempunyai banyak kelebihan dan khasiat dibanding air susu sapi (Zaenuri et al., 2003). Shodiq dan Zainal (2008) melaporkan, susu kambing memiliki khasiat menyembuhkan sakit kuning, asma, lelah (fatigue), eksim (penyakit kulit), migren (sakit kepala), bronchitis, TBC, asam urat, impotensi dan tekanan darah tinggi. Di samping itu, lemak susu kambing lebih lembut dan mudah dicerna. Keempat, dibanding beternak sapi perah, biaya investasi untuk berternak kambing perah relatif lebih murah dan secara teknis lebih mudah dilakukan oleh peternak.

Kualitas susu kambing juga sudah memenuhi Standard Nasional Indonesia (SNI). Dibandingkan dengan kandungan protein susu kedelai 3,5 g/100 g (Astawan, 2008), kandungan protein susu kambing lebih tinggi yaitu 3,6 g/100 g (Shodiq dan Zaenal ,2008; Moelijanto et al., 2002). Artinya, susu kambing sudah melampaui 
persyaratan minimal mutu protein sesuai standard SNI yaitu 2,7\% (BSN, 1998).

Kendala yang sering dihadapi oleh peternak kambing PE adalah menurunnya produktifitas kambing akibat menurunnya materi genetik karena tidak pernah dilakukan upaya re-breed dengan kambing PE murni. Zaenuri et al. (2003) menjelaskan, grading up bisa dilakukan dengan cara diinseminasi dengan semen beku kambing PE yang sudah teruji kualitas genetiknya. Selain dengan kambing PE bisa juga dilakukan menggunakan kambing Boer sehingga ternak hasil persilangannya akan menjadi ternak dwi fungsi yaitu sebagai penghasil susu dan daging yang pada akhirnya nilai ekonomi ternak akan meningkat secara signifikan (Zaenuri et al., 2005a dan 2005b).

Salah satu kendala pelaksanaan inseminasi buatan adalah waktu IB sering tidak tepat sehingga tingkat kebuntingannya rendah. Hal ini terjadi karena peternak tidak memberikan laporan yang akurat kepada inseminator mengenai ternaknya yang sedang birahi. Selain itu, birahi alami pada sekelompok kambing betina tidak terjadi secara serentak sehingga IB tidak bisa dilakukan serentak. Untuk mempermudah pelaksanaan inseminasi pada sekelompok ternak maka harus dilakukan penyerentakan birahi. Keuntungan penyerentakan birahi adalah sekelompok ternak akan birahi dan diinseminasi relatif serentak, sehingga kelahiran anak akan terjadi pada waktu relatif bersamaan, manajemen pemeliharaan dan penjualan menjadi lebih mudah (Zaenuri et al., 2016).

Berdasarkan uraian diatas, kegiatan pengabdian kepada masyarakat ini dilakukan dengan tujuan: pertama, memperkenalkan peternak kepada teknologi sederhana metode perangsang dan penyerentak birahi pada kambing. Kedua, meningkatkan efisiensi reproduksi melalui efisiensi waktu deteksi birahi sehingga perkawinan atau inseminasi ternak bisa dilaksanakan serentak dan tepat waktu. Terakhir, meningkatkan dan menyeragamkan waktu kelahiran anak kambing sehingga pemeliharaan ternak menjadi lebih terencana dan sesuai umur ternaknya.

\section{METODE KEGIATAN}

\section{Metode pendekatan}

Kegiatan penyuluhan dilaksanakan dengan metode Innovative Approach (Amir dan Knipsheer, 1989) yang menekankan pada pendekatan partisipatif. Tujuan metode ini antara lain adalah : 1). Meningkatkan dialog diantara sesama peternak untuk meningkatkan adopsi inovasi, 2). Diskusi dan mengevaluasi hasil kegiatan dilakukan secara kekeluargaan untuk memperoleh kesamaan pemahaman materi yang disampaikan dan 3). Merangsang tumbuhnya kontribusi dari pengalaman dan pengetahuan asli peternak (indigenous knowledge) terhadap peternak lainnya.

\section{Sasaran Pengabdian Pada Masyarakat}

Sasaran kegiatan PPM adalah peternak kambing yang aktif dan tercatat sebagai anggota kelompok peternak kambing "Harapan Makmur, Geger Girang dan Sejahtera Abadi" desa Aik Mual kecamatan Praya, kabupaten Lombok Tengah. Setiap kelompok diwakili 15 orang sehingga jumlah seluruh peserta kegiatan PPM sebanyak 45 orang. Populasi kambing ditiga kelompok tersebut kurang lebih 950 ekor yang terdiri dari berbagai tingkatan umur.

\section{Pelaksanaan Kegiatan}

Untuk mempermudah deteksi birahi dan inseminasi buatan dilakukan dengan memperkenalkan tiga jenis cara penyerentakan birahi pada kambing yaitu : Hand made progesterone spong (HMPS) produksi Laboratorium Reproduksi 
Fakkultas Peternakan, Unram (Produk program MP3EI), Controled Internal Drug Release (EAZI-BREED CIDR, New Zealand) dan Prostaglandin F2alfa (Merk Enzopres, Produksi Wonder). Sementara, untuk meningkatkan pengetahuan peternak mengenai efek perlakuan penyerentakan birahi tersebut terhadap keserentakan birahi pada kambing dijelaskan menggunakan secara lisan dibantu tayangan gambar melalui LCD dan diskusi atau Tanya jawab.

\section{Evaluasi Hasil Pelaksanaan}

Untuk mengukur keberhasilan pelaksanaan PPM, dilakukan evaluasi terhadap dua aspek yaitu respon peserta terhadap materi penyuluhan yang diberikan dengan cara menilai antusiasme peserta selama pelaksanaan PPM yang tercermin dari keaktifan peserta bertanya, diskusi dan tanya jawab. Kedua, evaluasi terhadap kesesuaian materi penyuluhan yang diberikan dengan kebutuhan peserta yang dilakukan dengan mengajukan daftar pertanyaan dipandu oleh tim pelaksana.

\section{HASIL DAN PEMBAHASAN}

Kegiatan pengabdian kepada masyarakat diikuti oleh 45 orang peternak kambing PE yang tergabung dalam tiga kelompok peternak kambing yaitu "Harapan Makmur, Geger Girang dan Sejahtera Abadi " desa Aik Mual Kecamatan Praya. Kegiatan utama adalah ceramah dan diskusi atau tanya jawab, selanjutnya kunjungan kebeberapa kandang peternak dan diskusi lapangan dengan seluruh peserta (Gambar 1).

Materi pengabdian kepada masyarakat mendapat respon yang sangat baik dari seluruh peserta. Hal ini diketahui dari antusiasme peserta selama penyampaian meteri serta pada saat diskusi dan tanya jawab. Jumlah pertanyaan dibatasi, sehingga disepakati setiap kelompok diwakili oleh 5 orang anggota kelompoknya atau 15 orang peserta dengan berbagai jenis pertanyaan dan saran.

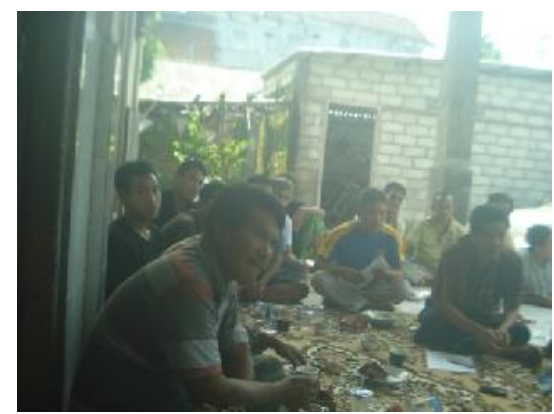

Gambar 1. Peserta sedang menyimak presentasi materi pengabdian

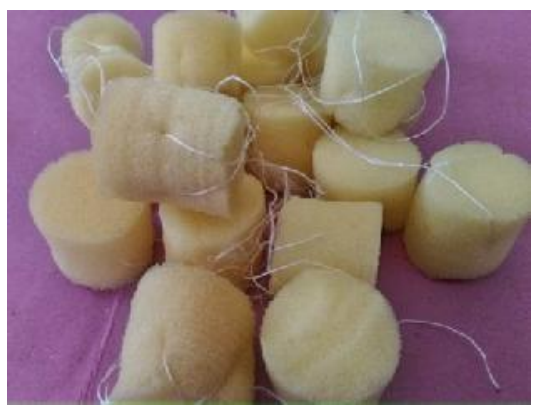

Gambar 2. Hand Made Progesterone Spong (HMPS) untuk penyerentak birahi Kambing

Ada beberapa faktor yang mendukung pelaksanaan PPM ini terlaksana sesuai target dan tujuan yang ditetapkan. Pertama, kambing PE di desa Aik Mual, khususnya di 3 kelompok kelompok peternak kambing PE mulai dikenal sejak Empat tahun terakhir. Saat ini popularitas kambing PE sudah mulai menyebar dibeberapa desa tetanganya. Kedua, motivasi peternak kambing PE sangat tinggi, terbukti tiga tahun terakhir kelompok peternak kambing PE desa Aik Mual sudah menyelanggarakan kontes kambing PE tingkat kabupaten dan mendapat sambutan luar biasa dari berbagai peternak kambing tidak hanya di desa Aik Mual tetapi dari beberapa desa tetangganya. Kedua kontes tersebut dikoordinir oleh tim dari Fakultas Peternakan Unram, khususnya 
yang terlibat dalam kegiatan PPM ini. Ketiga, dengan adanya kontes tersebut, timbul kesadaran dan keinginan dari seluruh peternak khsusnya 3 kelompok peserta PPM untuk meningkatkan kualitas ternaknya.

Selanjutnya, materi pengabdian yang dipresentasikan sangat sesuai dengan keinginan dan kebutuhan mereka, sehingga mereka sangat mengharapkan adanya tindak lanjut dari meteri penyuluhan yang diberikan dalam bentuk penyerentakan birahi dan Inseminasi menggunakan semen beku kambig PE maupun kembing Boer.

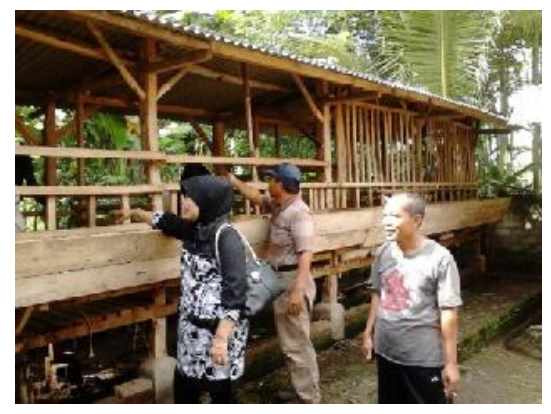

Gambar 3. Salah satu kandang kambing milik anggota kelompok "Harapan makmur"

Disamping antusiasme peternak, faktor lainnya yang mendukung adalah ketersediaan bibit kambing PE dalam bentuk semen beku dihampir setiap Poskeswan setiap kecamatan. Inseminasi pada ternak kambing belum seintensif inseminasi pada ternak sapi. Akibatnya, tidak semua inseminator terampil malakukan inseminasi pada ternak kambing.

\section{KESIMPULAN DAN SARAN}

Pengabdian Pada mayarakat di desa Aik Mual telah dilaksanakan dengan hasil sesuai dengan targetyang telah ditetapkan. Sinkronisasi birahi pada kambing adalah metode yang sangat efektif, mudah dan murah untuk mempermudah keserentakan birahi, deteksi birahi dan keserentakan pelaksanaan inseminasi pada kambing.

Kegiatan pengabdian kepada masyarakat yang telah dillaksanakan ini perlu ditindak lanjuti dengan program pelayanan yaitu pelayanan sinkronisasi birahi dan inseminasi buatan menggunakan semen beku kambing PE sehingga kualitas genetik kambing PE yang ada di desa Aik Mual bisa dipertahankan.

\section{UCAPAN TERIMA KASIH}

Tim PPM menyampaikan terima kasih kepada Direktur Riset dan Pengembangan Kementrian Riset, Teknologi dan Pendidikan Tinggi. Kegiatan ini adalah salah satu sub bagian kegiatan program Penelitian Prioritas Nasional Masterplan Percepatan daPerluasan Pembangunan Ekonomi Indonesia 2011-2015 (PENPRINAS MP3EI 2011-2025) Tahun anggaran 2016-2019)..

\section{DAFTAR PUSTAKA}

Astawan, Made dan Tutik Wresdiyati. 2004. Diet Sehat dengan Makanan Berserat. Tiga Serangkai. Solo.

Amir P. dan knipscheer H.C. 1989. Conductig on-farm research. Procedures and economic analiysis. Winrock international institute for agriculture development and international development research center.

Badan Standarisasi Nasional. 1998. SNI 013141-1998. Standar Mutu Susu Segar. Jakarta.

Moelijanto, R. Damayanti dan Bernadius. 2002. Khasiat dan Manfaat Susu Kambing. Jakarta: Agromedia

Shodiq, A dan Zainal, A. 2008. Meningkatkan Produksi Susu Kambing Peranakan Etawa. Jakarta: 
Agromedia Pustaka. Moelijanto, R. Damayanti dan Bernadius. 2002. Khasiat dan Manfaat Susu Kambing. Jakarta: Agromedia.

Zaenuri, L.A. 2005a. Kinerja produksi dan reproduksi ternak kambing lokal yang disilangkan dengan kambing boar. Jurnal Ilmu Dan Teknologi Peternakan. Fakultas Peternakan. Universitas Mataram. Vol. 4. pp. 226-233

Zaenuri, L. A. 2005b. Mengatasi kendala teknis perkawinan alam antara kambing PE dengan kambng lokal dengan cara sinkronisasi birahi dan inseminasi buatan. Journal Lemlit, vol. 2 No 28. Universitas Mataram. Mataram.

Zaenuri, L. A. 2003. Inseminasi buatan menggunakan semen beku kambig Boer untuk meningkatkan produktifitas kambing lokal. Laporan hasil pelaksanaan, kerjasama Fakultas Peternakan Unram, Yayasan Olat Parigi Kecamatan Jereweh Kabupaten Sumbawa dan PT. Newmont Nusa Tenggara.

Zaenur L. A. dan Rodiah. 2016. Efektifitas Progesteron Kering dan Basah Sebagai Perangsang Birahi Ternak Kambing. Jurnal Ilmu dan Teknologi Peternakan Indonesia Volume 2 (1): 129 - 133 